\title{
Sensory and nutritional evaluation of beverages developed using malted ragi (Eleusine coracana)
}

\author{
Megha Bansal and Navjot Kaur \\ Department of Food and Nutrition, Punjab Agricultural University, Ludhiana (Punjab), INDIA \\ *Corresponding author. E-mail:meghabansal283@gmail.com \\ Received: September 18, 2017; Revised received: October 14, 2017; Accepted: February 2, 2018
}

\begin{abstract}
Five milk based beverages were developed by supplementing malted ragi and were organoleptically evaluated for sensory attributes by semi-trained panel of 10 judges. Control samples were developed by using milk, fruits (banana, kiwi, strawberry, papaya and mango) and honey and in test samples malted ragi was added at different levels ranging from 5-15 percent. Results revealed that banana based malted ragi beverage supplemented with 5 percent malted ragi was overall highly acceptable in terms of all sensory attributes. The most accepted level was chemically analysed for proximate composition, amino acids, vitamins, minerals, available carbohydrates and antinutritional components by using standard methods. The most acceptable malted ragi beverage was estimated to have $11.78 \pm 0.06 \mathrm{~g}$ crude protein, $6.81 \pm 0.51 \mathrm{~g}$ of crude fat, $1.21 \pm 0.07 \mathrm{~g}$ of crude fibre, $27.44 \pm 1.03 \mathrm{~g}$ of carbohydrates, $594.3 \pm 4.5 \mathrm{mg}$ of tryptophan, $517.6 \pm 23.2 \mathrm{mg}$ of methionine, $372.3 \pm 8.5 \mathrm{mg}$ of lysine, $172.6 \mathrm{mg}$ of calcium, $3.73 \mathrm{mg}$ of iron, $102.2 \mathrm{mg}$ of phosphorus and $0.596 \mathrm{mg}$ of zinc per $100 \mathrm{ml}$. The anti-nutritional components were $155.8 \pm 11.3 \mathrm{mg}$ of phytates, $15.4 \pm 2.3 \mathrm{mg}$ of total phenols and $0.32 \pm 0.01 \mathrm{mg}$ of trypsin inhibitor activity. Total sugars were found to be $5.44 \pm 0.21 \mathrm{~g}, 3.16 \pm 0.15 \mathrm{~g}$ of reducing sugars, $2.28 \pm 0.14 \mathrm{~g}$ of non-reducing sugars and $1.06 \pm 0.05 \mathrm{~g}$ of starch. It may be concluded that malted ragi can be utilized successfully up to 5 percent level to prepare beverages with high nutritional value without imposing negative impact on sensory attributes which may prove a boon to osteoporotic patients.
\end{abstract}

Keywords: Nutritional evaluation, Organoleptic evaluation, Osteoporosis, Ragi

\section{INTRODUCTION}

Worldwide, osteoporosis causes more than 8.9 million fractures annually, resulting in an osteoporotic fracture every 3 seconds. Osteoporosis is estimated to affect 200 million women worldwide - approximately onetenth of women aged 60 , one-fifth of women aged 70 , two-fifths of women aged 80 and two-thirds of women aged 90. While data on prevalence of osteoporosis among women in India come from studies conducted in small groups spread across the country, estimates suggest that of the 230 million Indians expected to be over the age of 50 years in 2015, $20 \%$, ie, $\sim 46$ million, are women with osteoporosis. To maintain healthy life by public health strategy, the major aim is to promote nutritious diet to encourage healthy ageing and prevent early onset of chronic diseases. Various studies have shown that consumption of nutraceutical foods may provide greater health benefits. Nutraceutical, often used in nutrient premixes, is a substance that provides medical, health benefits including the prevention and treatment of disease. Such foods items or food components that help in prevention or treatment of diseases are made from herbal/ botanical raw materials. The total production of millets around the world was 762,712 metric tons in the year 2013 with the top production in India, contributing with 43.85 percent (Chandra et al., 2016). It was estimated that ragi shares ten percent of the thirty million tons of world's millet production (Dida et al., 2008). Finger millet or ragi (Eleusine coracana) having nutraceutical properties, is the oldest cereal grain in India which is fairly grown in extreme climatic conditions such as dry soil and poor fertilizers. Ragi is grown with minimal water resources. In some countries this crop is referred as "poor people's crop". Ragi is a rich source of calcium which is thirty times more than that of rice and wheat (Srivastava and Sharma 2012). In India, ragi (Eleusine coracana (L.) Gaertn) occupies maximal area among the small millets. The world total production of millet grains in year 2013 was 762,712 metric tons and the top producer was India with an annual output of 334,500 tons contributing $43.85 \%$. It is rich source of calcium $(0.34 \%)$, dietary fibre $(18 \%)$, phytates $(0.48 \%)$, protein $(6 \%-13 \%)$, minerals $(2.5 \%-3.5 \%)$ and phenolics $(0.3 \%-3 \%)$. Also, it has good amounts of thiamine, riboflavin, iron, methionine, isoleucine, leucine, phenylalanine and other essential amino acids. The abundance of these phytochemicals enhances the nutraceutical potential of fin- 
ger millet, making it a powerhouse of health benefitting nutrients. It has distinguished health beneficial properties, such as anti-diabetic (type 2 diabetes mellitus), anti-diarrheal, antiulcer, anti-inflammatory, atherosclerogenic, antimicrobial and antioxidant properties (Chandra et al., 2016).

Osteoporosis is the most common bone disease in humans, representing a major public health problem characterized by low bone mass, deterioration of bone tissue and disruption of bone architecture, compromised bone strength, and an increase in the risk of fracture. Osteoporosis affects an enormous number of people, of both sexes and all races, and its prevalence will increase as the population ages. (Cosman et al., 2014). Because the body does not make calcium it must be taken from the foods. The amount of calcium needed in diet every day is 1,200 milligrams for adults over 50 years old, 1,000 mg for adults ages 19 to 50 and 1,300 mg for children ages 9 to 18 . Getting at least the minimum recommended amount of needed calcium is the only effective means of treating the people with osteoporosis (Sullivan, 2009). To prevent the risk of developing osteoporosis one should change his lifestyle such as quitting smoking, reducing alcohol consumption, taking regular exercise and eating a well-balanced diet. There is an increasing trend in research, focusing on the application of alternative grains such as ragi (finger millet) which is potentially healthy to prevent the increasing calcium deficiency among individuals. Tripathi et al. (2014) developed a calcium rich instant health beverage powder from malted and extruded ragi (Eleusine coracana) with glucose, gurhal powder (Hibiscus rosa-sinensis), citric acid and vanilla essence. Before consumption the powder was dissolved and stirred in water. In addition, the instant health beverage powder was analysed for nutritional composition and results showed that beverage powder had a high content of protein $(12.25 \%)$ and calcium $(96.5 \%)$ along with neutraceutical properties. So the study concluded that malted ragi can be used as a supplement for calcium deficit women.

Ragi and its flour can be great substitute for other grains such as rice, wheat and other starchy grains and now a days it is widely used in new product development. Addition of malted ragi in milk can boost up the nutrient content of beverages. Devi et al. (2014) Supplementation of beverages with malted ragi and exotic fruits can positively affect plasma lipid profile and antioxidant activity of a person. Due to its high calcium content and easy digestibility, ragi grains in malted form can be used for the prevention of the risks of calcium deficiency. Thus, keeping in view all the properties of ragi, the study was planned to develop malted ragi beverages by using milk, ragi, honey and different fruit combinations. The combination of these ingredients will fulfil the daily requirements of the individuals and also provide good mouthfeel, taste and flavour to the beverages. The present study was carried out to study the development, sensory and nutritional evaluation of malted ragi beverages.

\section{MATERIALS AND METHODS}

Procurement and processing of ragi grains: Ragi (Eleusine coracana) have been procured in bulk from the local market. Milk, fruits (banana, kiwi, strawberry, papaya and mango) and honey were also purchased from local market. Ragi grains were thoroughly cleaned under running water to remove dust and foreign particles. The clean grains were then steeped in water at room temperature overnight and germinated by spreading ragi grains on a thin cloth and bringing the edges of the towel and tie the grains loosely with the cloth. Place the cloth back in the colander for 48 hours at $28 \pm 1^{\circ} \mathrm{C}$. Germinated grains were dried in hot air oven at $50 \pm 2^{\circ} \mathrm{C}$ for 24 hours. Malt was roasted in skillet at slow heat till the aroma developed and further ground in electric mixer to obtain fine flour. This whole flour was used in the development of malted ragi beverages.

Development of malted ragi beverages: Five milk based beverages were developed using malted ragi powder in the food laboratory of Department of Food and Nutrition, College of Home Science, Punjab Agriculture University, Ludhiana. Control samples were developed by using milk, fruits (banana, Musa; kiwi, Apteryx; strawberry, Fragaria $\times$ ananassa; papaya, Carica papaya and mango, Mangifera indica) and honey whereas experimental beverages were developed by incorporating malted ragi at different levels ranging from 5-15 percent.

\section{Recipe of the developed beverages by incorporating malted ragi powder \\ Ingredients \\ Milk $-200 \mathrm{ml}$ \\ Fruit $-45 \mathrm{~g}$ \\ Honey $-5 \mathrm{~g}$ \\ Ragi-5-15 g}

Method: Fruit was cleaned, skin was removed and fruit was chopped into equal pieces. In the next step, milk and chopped fruit were combined and blended properly with the help of blender. Honey was added and again mixture was blended. Strain the mixture to remove seeds of fruit (kiwi and strawberry).

Number of servings: 1

Volume per serving: $250 \mathrm{ml}$

Sensory evaluation: Malted ragi beverages were presented for sensory evaluation immediately after development. Organoleptic characteristics of beverages was determined using a panel consisting of 10 judges who were familiar with the major sensory attributes of food products. The panelists were asked to evaluate the beverages for appearance, colour, texture, flavour and overall acceptability. Each day four samples having one control and three experimental samples were pre- 
sented in identical containers coded with different numbers and serve simultaneously. Each sample was repeated thrice during course of evaluation. The rating was done on 9 point hedonic rating scale (Rangana 1979). The degree to which a product was liked was expressed as liked extremely ( 8 points), like very much (7 points), liked moderately (6 points), liked slightly (5 points), disliked slightly (4 points), disliked moderately (3 points), disliked very much ( 2 points) and disliked extremely (1 point). The testing was conducted in Food laboratory of Department of Food and Nutrition, College of Home Science, Punjab Agricultural University, Ludhiana.

Chemical analysis: The sample with highest acceptability score was thoroughly mixed in a blender and weighed quantity of sample was taken for analysis. It was dried in oven at $60^{\circ} \mathrm{C}$ in petri dishes for four hours. The dried sample was ground to fine powder and stored in airtight polythene bags for further chemical analysis.

Proximate composition with crude protein, crude fat, crude fibre, ash and minerals were analysed by using standard methods (AOAC 2000). For total minerals, samples were wet digested in hot plate using nitric acid and perchloric acid mixture in 5:1 ratio (v/v) and used for the determination of total amount of calcium, iron, zinc and phosphorus by atomic absorption spectrophotometry (AOAC 2000). The amino acid content of beverage sample was evaluated. Tryptophan and methionine were estimated by the procedure used by Concon (1975) and Horn et al (1946), respectively. The estimation of available lysine was carried out by the method giver by Carpenter (1960). The available carbohydrate content like total sugars (Dubois et al 1956), reducing sugars (Nelson 1944), non-reducing sugars and starch (Clegg 1956) were estimated spectrophotometrically by using spectrophotometer-20. The antinutritional factors such as phytates and total phenols (mg/ 100g) were estimated by the procedure used by Haug and Lantzsch (1983) and AOAC (1985), respectively. The estimation of trypsin inhibitor activity was carried out by the method giver by Roy and Rao (1971).

Statistical analysis: The data was analysed with the help of various statistical tools such as mean and standard deviation.

\section{RESULTS}

Table 1. Mango beverage supplemented with malted ragi.

\begin{tabular}{llllll}
\hline Name of recipe & Ingredients & C & M1 & M2 & M3 \\
\hline \multirow{3}{*}{ Mango beverage } & Milk & $210 \mathrm{ml}$ & $210 \mathrm{ml}$ & $210 \mathrm{ml}$ & $210 \mathrm{ml}$ \\
& Mango & $35 \mathrm{~g}$ & $30 \mathrm{~g}$ & $25 \mathrm{~g}$ & $20 \mathrm{~g}$ \\
& Honey & $5 \mathrm{~g}$ & $5 \mathrm{~g}$ & $5 \mathrm{~g}$ & $5 \mathrm{~g}$ \\
& Malted rag powder & - & $5 \mathrm{~g}$ & $10 \mathrm{~g}$ & $15 \mathrm{~g}$ \\
\hline
\end{tabular}

$\mathrm{C}($ Control $)=35 \mathrm{~g}$ mango $+5 \mathrm{~g}$ honey and milk to make volume $250 \mathrm{ml}, \mathrm{M} 1=30 \mathrm{~g}$ mango $+5 \mathrm{~g}$ honey $+5 \mathrm{~g}$ malted ragi and milk to make volume $250 \mathrm{ml}, \mathrm{M} 2=25 \mathrm{~g}$ mango $+5 \mathrm{~g}$ honey $+10 \mathrm{~g}$ malted ragi and milk to make volume $250 \mathrm{ml}, \mathrm{M} 3=20 \mathrm{~g}$ mango $+5 \mathrm{~g}$ honey $+15 \mathrm{~g}$ malted ragi and milk to make volume $250 \mathrm{ml}$

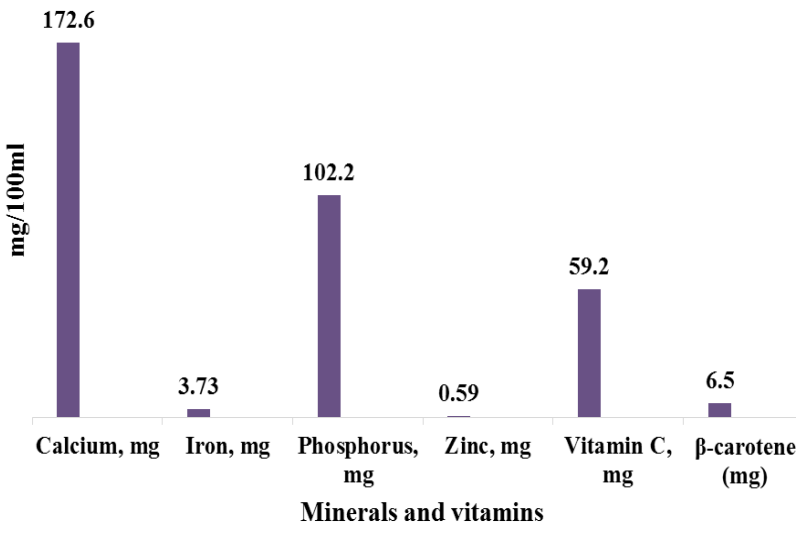

Fig 1. Mineral and vitamin content of malted ragi beverage per $100 \mathrm{ml}$ (dry weight basis).

Sensory evaluation of developed beverages: sensory evaluation of different malted ragi beverages is shown in tables 6-10.

Organoleptic evaluation of mango beverage supplemented with malted ragi: The scores given by the panel of judges revealed that on the basis of overall acceptability scores, control (C) scored higher and was most acceptable whereas mango beverage with 15 percent malted ragi (M3) was least acceptable (Table 6). The mango beverage with 15 percent malted ragi was given scores ranging from 6.60 to 7.00 . It was observed that control sample was found to have highest mean scores for the appearance, colour, texture, flavour and taste ranging from 7.20 to 7.70 with an overall acceptability score of 7.44 , followed by mango beverage supplemented with 5 percent malted ragi (M1) with an overall acceptability score of 7.22 and resulted in moderate likeness. The mean scores for overall acceptability was lower for (M2) with an overall acceptability score of 7.10 and resulted in mild likeness.

A significant difference $(\mathrm{P} \leq 0.05)$ was found in the control and test samples i.e. M1, M2 and M3 for colour of mango beverage. C, M1 and M2 samples obtained similar mean scores for flavour i.e. 7.20. $\mathrm{C}$ and M2 sample obtained similar mean score for taste i.e. 7.20. The result revealed that the highest scores for texture 7.40 were obtained by $\mathrm{C}$ followed by $\mathrm{M} 1$ and 6.80 scores were obtained by M3. Results also revealed the decrease in mean scores with the increase of levels of supplementation of malted ragi. Singh and Kochhar (2012) showed that the highest overall acceptability scores was given by the panel of judges to 
Table 2. Banana beverage supplemented with malted ragi.

\begin{tabular}{llllll}
\hline Name of recipe & Ingredients & C & B1 & B2 & B3 \\
\hline \multirow{3}{*}{ Banana beverage } & Milk & $210 \mathrm{ml}$ & $210 \mathrm{ml}$ & $210 \mathrm{ml}$ & $210 \mathrm{ml}$ \\
& Banana & $35 \mathrm{~g}$ & $30 \mathrm{~g}$ & $25 \mathrm{~g}$ & $20 \mathrm{~g}$ \\
& Honey & $5 \mathrm{~g}$ & $5 \mathrm{~g}$ & $5 \mathrm{~g}$ & $5 \mathrm{~g}$ \\
& Malted ragi powder & - & $5 \mathrm{~g}$ & $10 \mathrm{~g}$ & $15 \mathrm{~g}$ \\
\hline
\end{tabular}

$\mathrm{C}(\mathrm{Control})=35 \mathrm{~g}$ banana $+5 \mathrm{~g}$ honey and milk to make volume $250 \mathrm{ml}, \mathrm{B} 1=30 \mathrm{~g}$ banana $+5 \mathrm{~g}$ honey $+5 \mathrm{~g}$ malted ragi and milk to make volume $250 \mathrm{ml}, \mathrm{B} 2=25 \mathrm{~g}$ banana $+5 \mathrm{~g}$ honey $+10 \mathrm{~g}$ malted ragi and milk to make volume $250 \mathrm{ml}, \mathrm{B} 3=20 \mathrm{~g}$ banana $+5 \mathrm{~g}$ honey $+15 \mathrm{~g}$ malted ragi and milk to make volume $250 \mathrm{ml}$

Table 3. Papaya beverage supplemented with malted ragi.

\begin{tabular}{llllll}
\hline Name of recipe & Ingredients & C & P1 & P2 & P3 \\
\hline \multirow{3}{*}{ Papaya beverage } & Milk & $210 \mathrm{ml}$ & $210 \mathrm{ml}$ & $210 \mathrm{ml}$ & $210 \mathrm{ml}$ \\
& Papaya & $35 \mathrm{~g}$ & $30 \mathrm{~g}$ & $25 \mathrm{~g}$ & $20 \mathrm{~g}$ \\
& Honey & $5 \mathrm{~g}$ & $5 \mathrm{~g}$ & $5 \mathrm{~g}$ & $5 \mathrm{~g}$ \\
& Malted ragi powder & - & $5 \mathrm{~g}$ & $10 \mathrm{~g}$ & $15 \mathrm{~g}$ \\
\hline
\end{tabular}

$\mathrm{C}($ Control $)=35 \mathrm{~g}$ papaya $+5 \mathrm{~g}$ honey and milk to make volume $250 \mathrm{ml}, \mathrm{P} 1=30 \mathrm{~g}$ papaya $+5 \mathrm{~g}$ honey $+5 \mathrm{~g}$ malted ragi and milk to make volume $250 \mathrm{ml}, \mathrm{P} 2=25 \mathrm{~g}$ papaya $+5 \mathrm{~g}$ honey $+10 \mathrm{~g}$ malted ragi and milk to make volume $250 \mathrm{ml}, \mathrm{P} 3=20 \mathrm{~g}$ papa$\mathrm{ya}+5 \mathrm{~g}$ honey $+15 \mathrm{~g}$ malted ragi and milk to make volume $250 \mathrm{ml}$

Table 4. Strawberry beverage supplemented with malted ragi.

\begin{tabular}{llllll}
\hline Name of recipe & Ingredients & C & S1 & S2 & S3 \\
\hline \multirow{3}{*}{ Strawberry beverage } & Milk & $210 \mathrm{ml}$ & $210 \mathrm{ml}$ & $210 \mathrm{ml}$ & $210 \mathrm{ml}$ \\
& Strawberry & $35 \mathrm{~g}$ & $30 \mathrm{~g}$ & $25 \mathrm{~g}$ & $20 \mathrm{~g}$ \\
& Honey & $5 \mathrm{~g}$ & $5 \mathrm{~g}$ & $5 \mathrm{~g}$ & $5 \mathrm{~g}$ \\
& Malted ragi powder & - & $5 \mathrm{~g}$ & $10 \mathrm{~g}$ & $15 \mathrm{~g}$ \\
\hline
\end{tabular}

$\mathrm{C}($ Control $)=35 \mathrm{~g}$ strawberry $+5 \mathrm{~g}$ honey and milk to make volume $250 \mathrm{ml}, \mathrm{S} 1=30 \mathrm{~g}$ strawberry $+5 \mathrm{~g}$ honey $+5 \mathrm{~g}$ malted ragi and milk to make volume $250 \mathrm{ml}, \mathrm{S} 2=25 \mathrm{~g}$ strawberry $+5 \mathrm{~g}$ honey $+10 \mathrm{~g}$ malted ragi and milk to make volume $250 \mathrm{ml}$, $\mathrm{S} 3=20 \mathrm{~g}$ strawberry $+5 \mathrm{~g}$ honey $+15 \mathrm{~g}$ malted ragi and milk to make volume $250 \mathrm{ml}$

Table 5. Kiwi beverage supplemented with malted ragi.

\begin{tabular}{llllll}
\hline Name of recipe & Ingredients & C & K1 & K2 & K3 \\
\hline \multirow{3}{*}{ Kiwi } & Milk & $210 \mathrm{ml}$ & $210 \mathrm{ml}$ & $210 \mathrm{ml}$ & $210 \mathrm{ml}$ \\
beverage & Kiwi & $35 \mathrm{~g}$ & $30 \mathrm{~g}$ & $25 \mathrm{~g}$ & $20 \mathrm{~g}$ \\
& Honey & $5 \mathrm{~g}$ & $5 \mathrm{~g}$ & $5 \mathrm{~g}$ & $5 \mathrm{~g}$ \\
& Malted ragi powder & - & $5 \mathrm{~g}$ & $10 \mathrm{~g}$ & $15 \mathrm{~g}$ \\
\hline
\end{tabular}

$\mathrm{C}($ Control $)=35 \mathrm{~g}$ kiwi fruit $+5 \mathrm{~g}$ honey and milk to make volume $250 \mathrm{ml}, \mathrm{K} 1=30 \mathrm{~g}$ kiwi fruit $+5 \mathrm{~g}$ honey $+5 \mathrm{~g}$ malted ragi and milk to make volume $250 \mathrm{ml}, \mathrm{K} 2=25 \mathrm{~g}$ kiwi fruit $+5 \mathrm{~g}$ honey $+10 \mathrm{~g}$ malted ragi and milk to make volume $250 \mathrm{ml}, \mathrm{K} 3=20$ $\mathrm{g}$ kiwi fruit $+5 \mathrm{~g}$ honey $+15 \mathrm{~g}$ malted ragi and milk to make volume $250 \mathrm{ml}$

the $\mathrm{S} 1$ level of drink which was prepared by using $5 \mathrm{~g}$ pearl millet, $2.5 \mathrm{~g}$ cauliflower leaf powder, $20 \mathrm{~g}$ banana, $10 \mathrm{~g}$ jaggery and $63 \mathrm{ml}$ whey water per $100 \mathrm{ml}$. The mean scores of M1 (7.22 \pm 0.56$)$ did not vary much in comparison to control $(\mathrm{C}, 7.44 \pm 0.59)$. Sheth and Hirdyani (2016) reported that salt- jeera flavoured barley fermented drink got maximum overall acceptability with the mean scores 17.51 followed by chocolate with the mean scores of 16.18. Salt-jeera had the highest score for good mouth feel i.e. 8.47, followed by chocolate and rose. None of the flavours of drink showed any defects.

Organoleptic evaluation of banana beverage supplemented with malted ragi: The scores given by the panel of judges showed that the highest mean scores were obtained by banana beverage (B1) supplemented with 5 percent malted ragi with the highest overall acceptability i.e. 8.48 and was most acceptable beverage by the judges whereas banana beverage (B3) supplemented with 15 percent malted ragi was least acceptable by the judges (Table 7). The overall acceptability of (B3) was found to be lowest i.e. 7.22. The mean scores of (B1) were found to be higher for appearance, colour, texture, flavour, taste and overall acceptability ranging from $8.20-8.70$, followed by banana beverage supplemented with 10 percent malted ragi (B2) with the overall acceptability of 7.76. The data showed significant results $(\mathrm{P} \leq 0.05)$ for $\mathrm{C}, \mathrm{B} 1, \mathrm{~B} 2$ and B3 in terms of all the sensory parameters.

Kumar et al. (2017) analysed the milk beverage prepared with corn flour, whey protein concentrate, banana pulp and sugar and reported that beverage with 1 percent corn flour, 1 percent whey protein concentrate, 15 percent banana pulp and 8 percent sugar was found to be highly acceptable among the other beverages.

Organoleptic evaluation of papaya beverage supplemented with malted ragi: The scores given by the judges showed that among all the test samples the 
Table 6. Organoleptic evaluation of mango beverage supplemented with malted ragi.

\begin{tabular}{lcccccc}
\hline S. No. & Appearance & Colour & Texture & Flavour & Taste & Overall acceptability \\
\hline C & $7.70 \pm 0.48$ & $7.70 \pm 0.48$ & $7.40 \pm 0.70$ & $7.20 \pm 0.79$ & $7.20 \pm 0.79$ & $7.44 \pm 0.59$ \\
M1 & $7.40 \pm 0.52$ & $7.30 \pm 0.48$ & $7.10 \pm 0.88$ & $7.20 \pm 0.79$ & $7.10 \pm 0.74$ & $7.22 \pm 0.56$ \\
M2 & $7.10 \pm 0.88$ & $7.00 \pm 0.94$ & $7.00 \pm 0.82$ & $7.20 \pm 0.79$ & $7.20 \pm 0.92$ & $7.10 \pm 0.78$ \\
M3 & $6.80 \pm 1.03$ & $6.60 \pm 0.84$ & $6.80 \pm 1.03$ & $7.00 \pm 1.15$ & $6.90 \pm 1.20$ & $6.82 \pm 0.99$ \\
F ratio & $2.57^{\text {NS }}$ & $4.19^{*}$ & $0.84^{\text {NS }}$ & $0.13^{\text {NS }}$ & $0.23^{\text {NS }}$ & $1.19^{\text {NS }}$ \\
C.D. & 0.47 & 0.45 & 0.54 & 0.46 & 0.58 & 0.46 \\
\hline
\end{tabular}

$\mathrm{C}($ Control $)=35 \mathrm{~g}$ mango $+5 \mathrm{~g}$ honey and milk to make volume $250 \mathrm{ml}, \mathrm{M} 1=30 \mathrm{~g}$ mango $+5 \mathrm{~g}$ honey $+5 \mathrm{~g}$ malted ragi and milk to make volume $250 \mathrm{ml}, \mathrm{M} 2=25 \mathrm{~g}$ mango $+5 \mathrm{~g}$ honey $+10 \mathrm{~g}$ malted ragi and milk to make volume $250 \mathrm{ml}, \mathrm{M} 3=20 \mathrm{~g}$ mango $+5 \mathrm{~g}$ honey $+15 \mathrm{~g}$ malted ragi and milk to make volume $250 \mathrm{ml}$, Values are Mean \pm S.D., * Values are significant at $5 \%$ level, NS - Non significant

Table 7. Organoleptic evaluation of banana beverage supplemented with malted ragi.

\begin{tabular}{lllllll}
\hline S. No. & Appearance & Colour & Texture & Flavour & Taste & Overall acceptability \\
\hline C & $7.80 \pm 0.42$ & $7.90 \pm 0.32$ & $7.80 \pm 0.63$ & $7.50 \pm 0.53$ & $7.60 \pm 0.52$ & $7.72 \pm 0.38$ \\
B1 & $8.30 \pm 0.48$ & $8.50 \pm 0.53$ & $8.20 \pm 0.63$ & $8.70 \pm 0.67$ & $8.70 \pm 0.67$ & $8.48 \pm 0.50$ \\
B2 & $7.60 \pm 0.70$ & $7.60 \pm 0.70$ & $7.60 \pm 0.84$ & $8.00 \pm 0.82$ & $8.00 \pm 0.82$ & $7.76 \pm 0.70$ \\
B3 & $7.10 \pm 0.57$ & $7.20 \pm 0.63$ & $7.20 \pm 0.79$ & $7.30 \pm 0.67$ & $7.30 \pm 0.67$ & $7.22 \pm 0.61$ \\
F ratio & $8.07^{*}$ & $9.47^{*}$ & $3.25^{*}$ & $8.39^{*}$ & $7.95^{*}$ & $8.60^{*}$ \\
C.D. & 0.34 & 0.35 & 0.45 & 0.42 & 0.42 & 0.35 \\
\hline
\end{tabular}

$\mathrm{C}(\mathrm{Control})=35 \mathrm{~g}$ banana $+5 \mathrm{~g}$ honey and milk to make volume $250 \mathrm{ml}, \mathrm{B} 1=30 \mathrm{~g}$ banana $+5 \mathrm{~g}$ honey $+5 \mathrm{~g}$ malted ragi and milk to make volume $250 \mathrm{ml}, \mathrm{B} 2=25 \mathrm{~g}$ banana $+5 \mathrm{~g}$ honey $+10 \mathrm{~g}$ malted ragi and milk to make volume $250 \mathrm{ml}, \mathrm{B} 3=20 \mathrm{~g}$ banana $+5 \mathrm{~g}$ honey $+15 \mathrm{~g}$ malted ragi and milk to make volume $250 \mathrm{ml}$, Values are Mean \pm S.D., $*$ Values are significant at $5 \%$ level

Table 8. Organoleptic evaluation of papaya beverage supplemented with malted ragi.

\begin{tabular}{lllllll}
\hline S. No. & Appearance & Colour & Texture & Flavour & Taste & Overall acceptability \\
\hline C & $7.20 \pm 0.63$ & $7.20 \pm 0.42$ & $7.30 \pm 0.67$ & $7.00 \pm 0.67$ & $7.10 \pm 0.74$ & $7.16 \pm 0.43$ \\
P1 & $7.10 \pm 0.74$ & $6.90 \pm 0.99$ & $7.10 \pm 0.99$ & $7.20 \pm 0.63$ & $7.20 \pm 0.63$ & $7.10 \pm 0.72$ \\
P2 & $6.70 \pm 0.82$ & $6.60 \pm 0.70$ & $7.00 \pm 0.82$ & $7.00 \pm 0.82$ & $7.00 \pm 0.82$ & $6.86 \pm 0.75$ \\
P3 & $5.90 \pm 1.20$ & $5.70 \pm 1.06$ & $6.30 \pm 1.16$ & $6.40 \pm 1.07$ & $6.50 \pm 1.18$ & $6.16 \pm 1.06$ \\
F ratio & $4.57^{*}$ & $6.05^{*}$ & $2.19^{\mathbf{N S}}$ & $1.80^{\mathbf{N S}}$ & $1.29^{\mathbf{N S}}$ & $3.53^{*}$ \\
C.D. & 0.54 & 0.52 & 0.58 & 0.51 & 0.54 & 0.48 \\
\hline
\end{tabular}

$\mathrm{C}(\mathrm{Control})=35 \mathrm{~g}$ papaya $+5 \mathrm{~g}$ honey and milk to make volume $250 \mathrm{ml}, \mathrm{P} 1=30 \mathrm{~g}$ papaya $+5 \mathrm{~g}$ honey $+5 \mathrm{~g}$ malted ragi and milk to make volume $250 \mathrm{ml}, \mathrm{P} 2=25 \mathrm{~g}$ papaya $+5 \mathrm{~g}$ honey $+10 \mathrm{~g}$ malted ragi and milk to make volume $250 \mathrm{ml}, \mathrm{P} 3=20 \mathrm{~g}$ papaya $+5 \mathrm{~g}$ honey $+15 \mathrm{~g}$ malted ragi and milk to make volume $250 \mathrm{ml}$, Values are Mean \pm S.D., * Values are significant at $5 \%$ level, NS - Non significant

Table 9. Organoleptic evaluation of strawberry beverage supplemented with malted ragi.

\begin{tabular}{lllllll}
\hline S. No. & Appearance & Colour & Texture & Flavour & Taste & $\begin{array}{l}\text { Overall } \\
\text { ceptability }\end{array}$ \\
\hline C & $7.80 \pm 0.63$ & $7.50 \pm 0.53$ & $7.30 \pm 0.67$ & $7.30 \pm 0.95$ & $7.40 \pm 0.84$ & $7.46 \pm 0.67$ \\
S1 & $7.50 \pm 0.53$ & $7.50 \pm 0.71$ & $7.40 \pm 0.97$ & $7.60 \pm 0.97$ & $7.60 \pm 0.97$ & $7.52 \pm 0.77$ \\
S2 & $7.10 \pm 0.88$ & $6.90 \pm 0.88$ & $6.80 \pm 1.14$ & $6.90 \pm 1.20$ & $7.00 \pm 0.94$ & $6.94 \pm 0.89$ \\
S3 & $6.30 \pm 0.67$ & $6.30 \pm 0.67$ & $6.10 \pm 0.99$ & $6.00 \pm 0.94$ & $6.10 \pm 0.88$ & $6.16 \pm 0.78$ \\
F ratio & $8.89 *$ & $6.60^{*}$ & $3.85^{*}$ & $4.65^{*}$ & $5.36^{*}$ & $6.49^{*}$ \\
C.D. & 0.43 & 0.44 & 0.59 & 0.63 & 0.56 & 0.48 \\
\hline
\end{tabular}

$\mathrm{C}(\mathrm{Control})=35 \mathrm{~g}$ strawberry $+5 \mathrm{~g}$ honey and milk to make volume $250 \mathrm{ml}, \mathrm{S} 1=30 \mathrm{~g}$ strawberry $+5 \mathrm{~g}$ honey $+5 \mathrm{~g}$ malted ragi and milk to make volume $250 \mathrm{ml}, \mathrm{S} 2=25 \mathrm{~g}$ strawberry $+5 \mathrm{~g}$ honey $+10 \mathrm{~g}$ malted ragi and milk to make volume $250 \mathrm{ml}, \mathrm{S} 3=$ $20 \mathrm{~g}$ strawberry $+5 \mathrm{~g}$ honey $+15 \mathrm{~g}$ malted ragi and milk to make volume $250 \mathrm{ml}$, Values are Mean \pm S.D., * Values are significant at 5\% level

papaya beverage supplemented with 5 percent malted ragi ( $\mathrm{P} 1)$ was found to be highly acceptable (Table 8 ), followed by papaya beverage supplemented with 10 percent malted ragi (P2). The overall acceptability of control (C) was maximum i.e. 7.16 with the slight difference of P1 with the overall acceptability of 7.10. Results revealed that with the increase in the levels of supplementation of malted ragi the mean scores were decreased. The papaya beverage supplemented with 15 percent malted ragi (P3) was found to be least acceptable with the mean overall acceptability of 6.16 that was not liked at all. From all the beverages, control (C) was highly acceptable in terms of texture, colour and appearance. The mean scores of (P3) were found to be lowest for appearance, colour, texture, flavour, taste and overall acceptability ranging from 5.70 to 
Megha Bansal and Navjot Kaur / J. Appl.\& Nat. Sci. 10(1): 279 - 286 (2018)

Table 10. Organoleptic evaluation of kiwi beverage supplemented with malted ragi.

\begin{tabular}{lllllll}
\hline S. No. & Appearance & Colour & Texture & Flavour & Taste & Overall acceptability \\
\hline C & $7.70 \pm 0.48$ & $7.50 \pm 0.53$ & $6.50 \pm 0.97$ & $5.80 \pm 0.79$ & $5.80 \pm 0.79$ & $6.72 \pm 0.50$ \\
K1 & $7.80 \pm 0.63$ & $7.80 \pm 0.63$ & $7.10 \pm 0.88$ & $7.00 \pm 1.15$ & $6.90 \pm 1.10$ & $7.32 \pm 0.70$ \\
K2 & $7.20 \pm 0.92$ & $7.00 \pm 1.15$ & $6.70 \pm 1.16$ & $6.30 \pm 1.06$ & $6.40 \pm 0.97$ & $6.72 \pm 0.82$ \\
K3 & $6.40 \pm 0.97$ & $6.20 \pm 0.79$ & $5.40 \pm 1.07$ & $5.20 \pm 1.14$ & $5.10 \pm 1.10$ & $5.66 \pm 0.67$ \\
F ratio & $6.79 *$ & $7.43^{*}$ & $5.03^{*}$ & $5.34^{*}$ & $6.07^{*}$ & $10.16^{*}$ \\
C.D. & 0.48 & 0.50 & 0.64 & 0.65 & 0.62 & 0.42 \\
\hline
\end{tabular}

$\mathrm{C}($ Control $)=35 \mathrm{~g}$ kiwi fruit $+5 \mathrm{~g}$ honey and milk to make volume $250 \mathrm{ml}, \mathrm{K} 1=30 \mathrm{~g}$ kiwi fruit $+5 \mathrm{~g}$ honey $+5 \mathrm{~g}$ malted ragi and milk to make volume $250 \mathrm{ml}, \mathrm{K} 2=25 \mathrm{~g}$ kiwi fruit $+5 \mathrm{~g}$ honey $+10 \mathrm{~g}$ malted ragi and milk to make volume $250 \mathrm{ml}, \mathrm{K} 3=20$ $\mathrm{g}$ kiwi fruit $+5 \mathrm{~g}$ honey $+15 \mathrm{~g}$ malted ragi and milk to make volume $250 \mathrm{ml}$, Values are Mean \pm S.D., * Values are significant at $5 \%$ level

Table 11. Proximate composition of malted ragi beverage per $100 \mathrm{ml}$ (dry weight basis).

\begin{tabular}{ll}
\hline Proximate composition & Banana beverage \\
\hline Moisture (\%) & $50.8 \pm 0.25$ \\
Crude Protein (\%) & $11.78 \pm 0.06$ \\
Crude Fat (\%) & $6.81 \pm 0.51$ \\
Crude Fibre (\%) & $1.21 \pm 0.07$ \\
Ash (\%) & $1.96 \pm 0.06$ \\
CHO (g) & $27.44 \pm 1.03$ \\
Energy (Kcal) & $218.19 \pm 6.25$ \\
\hline
\end{tabular}

Values are Mean \pm S.D.

Table 12. Amino acid content of malted ragi beverage per $100 \mathrm{ml}$ (dry weight basis).

\begin{tabular}{ll}
\hline Amino acids & Banana beverage \\
\hline Tryptophan (mg) & $594.3 \pm 4.5$ \\
Methionine (mg) & $517.6 \pm 23.2$ \\
Lysine (mg) & $372.3 \pm 8.5$ \\
\hline
\end{tabular}

Values are Mean \pm S.D.

6.50. Jothi et al. (2014) reported that mixed squash prepared from 40 percent carrot juice incorporation with 40 percent papaya and 20 percent banana juice was highly acceptable and indicated the commercial scope for developing nutritious squash from carrot, papaya and banana juice. Matsuura et al. (2004) showed that nectar produced with 37.5 percent papaya pulp, 7.5 percent passion fruit juice and 5.0 percent acerola pulp with addition of 15 percent sucrose was highly acceptable. Papaya pulp and sucrose positively affect the sensory acceptance of nectars.

Organoleptic evaluation of strawberry beverage supplemented with malted ragi: The scores given by semi-trained panel revealed that the highest mean scores for all the sensory parameters amongst the control and test samples were obtained by strawberry beverage supplemented with 5 percent malted ragi (S1) with the overall acceptability of 7.52 and was liked moderately (Table 9). The mean scores of (S1) were found to be higher in the range of 7.40-7.60, followed by control (C) for texture, flavour and taste. Strawberry beverage supplemented with 15 percent malted ragi (S3) was found to be least acceptable due to the bitter taste of the beverage. The result showed significant difference $(\mathrm{P} \leq 0.05)$ among appearance, colour, texture, flavour, taste and overall acceptability. $\mathrm{C}$ and S1
Table 13. Anti- nutritional components of malted ragi beverage per $100 \mathrm{ml}$.

\begin{tabular}{ll}
\hline Anti-nutritional factors & Banana beverage \\
\hline Phytates (mg) & $155.8 \pm 11.3$ \\
Total Phenols (mg) & $15.4 \pm 2.3$ \\
$\begin{array}{l}\text { Trypsin inhibitor activity } \\
(\mathrm{mg})\end{array}$ & $0.32 \pm 0.01$ \\
\hline Values are Mean \pm S.D. &
\end{tabular}

Table 14. Available carbohydrate content of malted ragi beverage per $100 \mathrm{ml}$ (dry weight basis).

\begin{tabular}{ll}
\hline Available carbohydrates & Banana beverage \\
\hline Total soluble sugars $(\mathrm{g})$ & $5.44 \pm 0.21$ \\
Reducing sugars $(\mathrm{g})$ & $3.16 \pm 0.15$ \\
Non reducing sugars $(\mathrm{g})$ & $2.28 \pm 0.14$ \\
Starch $(\mathrm{g})$ & $1.06 \pm 0.05$ \\
\hline Values are Mean + S. &
\end{tabular}

Values are Mean \pm S.D.

obtained similar mean scores for colour i.e. 7.5. C obtained highest mean scores for appearance followed by (S1). Strawberry beverage supplemented with 10 percent malted ragi (S2) was liked slightly as compared to (C) and (S1). Murtaza et al (2004) found that for commercial scale manufacturing strawberry drink can successfully be stored at refrigeration temperature due to its significant stability in colour, flavour and taste.

Organoleptic evaluation of kiwi beverage supplemented with malted ragi: The result revealed that highest scores for appearance, colour, texture, flavour and taste was obtained by $\mathrm{K} 1$ (5\%) ranging from 6.9 to 7.8 with an overall acceptability score of 7.32 being liked very much. (C) and (K1) obtained similar overall acceptability score i.e. 6.72 (Table 10).

Kiwi beverage supplemented with 15 percent malted ragi (K3) was least acceptable by the judges with the overall acceptability of 5.66 because the bitterness of beverage was increased with increased ratio of malted ragi with kiwi fruit. Results showed that with the increased levels of supplementation of malted ragi there was decrease in mean scores of acceptability. Sharma et al (2016) prepared antioxidant rich bitter gourd based functional squash by blending bitter gourd juice with kiwi fruit (Actinidiadeliciosa) juice in different ratios i.e. 90:10, 80:20, 70:30, 60:40 and 50:50. The study revealed that blending increased the ascorbic acid content (33\%) and total phenolics $(24 \%)$. The 
products exhibited only slight changes in their physico -chemical, nutritional and sensory characteristics during storage but they were acceptable up to the period of six months.

Chemical composition of most acceptable malted ragi beverage: The most acceptable malted ragi beverage i.e. banana beverage with 5 percent malted ragi was analysed chemically for proximate composition, amino acid content, mineral content, vitamin content, available carbohydrates and anti- nutritional components by using standard methods. The values have been calculated for $100 \mathrm{~g}$ of developed malted ragi beverage.

Proximate composition (dry weight basis): The most acceptable malted ragi beverage was found to be banana beverage supplemented with 5 percent malted ragi. The banana beverage had 50.8 percent of moisture, 11.78 percent crude protein, 6.81 percent of crude fat, 1.21 percent of crude fibre, 1.96 percent of ash, 27.44 $\mathrm{g}$ of carbohydrates and provided $218.19 \mathrm{Kcal}$ of energy as shown in Table 11. Swer et al. (2013) reported that papaya and banana incorporated pearl millet malt mixes had the moisture content of 11 and 10 percent, 8.58.45 percent protein, 3.9- 5.4 percent fat and 5.5- 2.6 percent crude fibre respectively on dry weight basis. Vasanthamani and Anuradha (2011) developed a pregame sports drink containing $5 \mathrm{~g}$ sprouted ragi powder, roasted bengal gram powder, green gram dhal powder and maize flour, $10 \mathrm{~g}$ sago powder and sugar, $20 \mathrm{~g}$ of glucose and $150 \mathrm{~g}$ of milk and reported that the drink provided $317 \mathrm{kcal}$ of energy, $8 \mathrm{~g}$ of protein, $62 \mathrm{~g}$ of carbohydrate and $8 \mathrm{~g}$ of fat.

Amino acid content (dry weight basis): The banana beverage supplemented with 5 percent malted ragi had $594.3 \mathrm{mg}$ of tryptophan, $517.6 \mathrm{mg}$ of methionine and $372.3 \mathrm{mg}$ of lysine as shown in Table 12. Palanisamy et al. (2011) reported that among finger millet and horse gram a significant increase was observed in total essential amino acids by 1.1 -fold at 16-hours fermentation with protein containing $48.68 \%$ of essential amino acids over total amino acids. Increase in lysine content was from 5.87 to $6.73 \mathrm{~g}$ of amino acid/100 $\mathrm{g}$ of total amino acids.

Mineral and vitamin content (dry weight basis): The banana beverage supplemented with 5 percent malted ragi had $172.6 \mathrm{mg}$ of calcium, $3.73 \mathrm{mg}$ of iron, $102.2 \mathrm{mg}$ of phosphorus and $0.596 \mathrm{mg}$ of zinc per 100 g. The concentration of vitamins in banana beverage was $59.2 \mathrm{mg}$ of vitamin $\mathrm{C}$ and $6500 \mu \mathrm{g}$ of $\beta$-carotene per 100 g (Fig. 1). Kapoor et al (2013) prepared and analyzed a health drink by incorporating pearl millet, whey water, broccoli leaf powder, banana and jaggery and found that $100 \mathrm{mg}$ of developed drink had mineral content including iron with $2.96 \mathrm{mg}$ and calcium with $167 \mathrm{mg}$. Ascorbic acid was $5.6 \mathrm{mg}$ and $\beta$-carotene was $1568 \mu \mathrm{g}$. Tripathi et al (2012) reported that the doublefortified sorghum and ragi flours contained bioaccessi- ble zinc contents of 1.63 and $0.83 \mathrm{mg} / 100 \mathrm{~g}$ respectively, while the respective bioaccessibleiron contents were 2.63 and $2.39 \mathrm{mg} / 100 \mathrm{~g}$.

Anti- nutritional components (dry weight basis): Abubakar et al. (2015) revealed that in unprocessed finger millet (Eleusinecoracana) the mineral composition was $\mathrm{Ca}, \mathrm{K}, \mathrm{Na}, \mathrm{Mg}, \mathrm{Zn}, \mathrm{Fe}$ and $\mathrm{Cr}$ levels being (174.58, 158.1, 24.372, 20.78, 0.533, 9.64 and 1.118 $\mathrm{mg} / 100 \mathrm{~g}$ ) respectively. Vitamin B6, B3, B1, B2 and E were $(167.7,11.24,332.24,125.66$ and $60.23 \mathrm{mg} / 100$ g) respectively. The banana beverage supplemented with 5 percent malted ragi had $155.8 \mathrm{mg}$ of phytates, $15.4 \mathrm{mg}$ of total phenols and $0.32 \mathrm{mg}$ of trypsin inhibitor activity (Table 13). Kapoor et al (2013) reported that drink prepared from pearl millet had total phenols content of $18.2 \mathrm{mg}$, oxalates content of $22.5 \mathrm{mg}$ and phytin phosphorus content of $32.68 \mathrm{mg}$.

Available carbohydrates content (dry weight basis): The banana beverage supplemented with 5 percent malted ragi had $5.44 \mathrm{~g}$ of total sugars, $3.16 \mathrm{~g}$ of reducing sugars, $2.28 \mathrm{~g}$ of non-reducing sugars and $1.06 \mathrm{~g}$ of starch (Table 14) while total sugars in raw ragi was found to be $0.34 \mathrm{~g} / 100 \mathrm{~g}$. Shukla and Srivastava (2014) reported that noodles incorporated with refined wheat flour contained highest amount of starch $(63.02 \%)$, amylose $(8.72 \%)$ and amylopectin (54.29\%) whereas, $50 \%$ finger millet incorporated noodles contained highest amount of crude fat $(1.15 \%)$, crude fibre $(1.28 \%)$, carbohydrate $(78.54 \%)$, insoluble dietary fibre $(5.45 \%)$ and soluble dietary fibre $(3.71 \%)$, respectively. So, finger millet flour incorporated noodles were found nutritious and showed hypoglycemic effect.

\section{Conclusion}

All the beverages developed by using malted ragi and different fruits were found to be acceptable at 5 percent supplementation of malted ragi. The results showed that from all the beverages the banana beverage supplemented with 5 percent malted ragi was most acceptable by the panel of judges. On the basis of results, it may be concluded that supplemented beverages with 10 percent level of malted ragi can be successfully developed with high nutritional value and without imposing a negative impact on sensory attributes, which can result in the improvement of calcium level among osteoporotic patients.

\section{REFERENCES}

Abubakar, A., Bala, S., Audu, E., Mohammad, S., Gero, M. and Lande, L. (2015). Characterization and the antinutritional composition of unprocessed finger millet (Eleusine coracana). Int. J. Fd. Nutr. Safety. $6: 117-24$.

AOAC. (1985). Official Methods of Analysis, 13th edition, Association of Official Analytical Chemists. Washington DC.

AOAC. (2000). Official Methods of Analysis, 13th edition, Association of Official Analytical Chemists. Washing- 
ton DC.

Carpenter, K.J. (1960). The estimation of available lysine in animal protein foods. J. Biochem. 77 :604-10.

Chandra, D., Chandra, S., Pallavi, and Sharma, A.K. (2016). Review of Finger millet (Eleusine coracana (L.) Gaertn): A power house of health benefiting nutrients. Fd. Sci. Hum. Well. 5 :149-55.

Clegg, K.M. (1956). The adaptation of anthrone reagent to the estimation of starch in cereals. J. Sci. Fd. Agri. $7: 40$.

Concon, J.M. (1975). Rapid and simple method for determination of tryptophan in cereal grains. Anal Biochem. $67: 206$.

Cosman, F., Beur, S.J., LeBoff, M.S., Lewiecki, E.M., Tanner, B., Randall, S. and Lindsay, R. (2014). Clinician's guide to prevention and treatment of osteoporosis. Osteoporos. Int. 25 :2359-81.

Devi, P.B., Vijayabharathi, R., Sathyabama, S., Malleshi, N.G., and Priyadarisini, V.B. (2014). Health benefits of finger millet (Eleusine coracana L.) polyphenols and dietary fiber: a review. J. Food Sci. Technol., $51: 1021-40$

Dida, M., Wanyera, N., Dunn, M.L., Bennetzen, J.L. and Devos, K.M. (2008). Population structure and diversity in finger millet (Eleusine coracana) germplasm. Tropical Plant Biol. $1: 131-141$

Dubois, M., Gilles, K.A., Hamilton, J.K., Rebers, P.A. and Smith, F. (1956). Colorimetric methods for determination of sugars and related substances. Anal Chem. $28: 350$.

Haug, W. and Lantzsch, H.T. (1983). Sensitive method for rigid determination of phytate in cereal and cereal products. J. Sci. Fd. Agri. $34: 1423$.

Horn, J.M., Jones, D.B. and Blum, A.E. (1946). Colorimetric determination of methionine in proteins and foods. $J$. BiolChem. $166: 313-20$.

Jothi, J.S., Karmoker, P. and Sarower, K. (2014). Quality assessment of mixed fruit squash: physico-chemical analysis, sensory evaluation and storage studies. $J$. Bangladesh Agri. Uni. 12 :195-201.

Kapoor, N., Kochhar, A., Madhu, and Kochhar, V. (2013). Sensory and nutritional evaluation of health drink for adolescent girls using underutilized foods. Fd. Sci. Res. J. $4: 7-11$.

Kumar, P., Peter, S. and Singh, S.B. (2017). Sensory evaluation of low fat cereal and fruit based fermented milk beverage. Pharma. Innovation J. $6: 37-39$.

Matsuura, F.C., Folegatti, M.I., Cardoso, R.L. and Ferreira, D.C. (2004). Sensory acceptance of mixed nectar of papaya, passion fruit and acerola. Sci. Agri. 61 :604-08.

Murtaza, M.A., Huma, N., Javaid, J., Shabbir, M.A., MueenUd Din, G. and Mahmood, S. (2004). Studies on stability of strawberry drink stored at different temperatures. Int. J. Agri. Biol. $6: 58-60$.

Nelson, N. (1944). A photometric adaptation of the Somogyi method for the determination of glucose. J. Bio. Chem. $153: 375-80$

Palanisamy, B., Rajendran, V., Sathyaseelan, S., Bhat, R. and Venkatesan, B. (2011). Enhancement of nutritional value of finger millet-based food (Indian $\operatorname{dos} a$ ) by cofermentation with horse gram flour. Int. J. Fd. Sci. Nutr. 63 :5-15.

Rangana, S. (1979). Manual of analysis of fruits and vegetable products. Tata Mc Graw-Hill. Pub.Co.Ltd. New Delhi p. 294-95.

Roy, D.N. and Rao, P.S. (1971). Evidence, isolation, precipitation and some properties of trypsin inhibitor in Lathyrus sativus. J. Agri. Fd. Chem. $19: 257$.

Sharma, R., Thakur, A., Joshi, V.K. and Sharma, V. (2016). Development and quality evaluation of bitter gourdkiwi blended squash during storage. Int. J. Fd. Ferment Technol. 6 :327-336.

Sheth, M. and Hirdyani, H. (2016). Development and sensory analysis of a buttermilk based fermented drink using barley and fructooligosaccharide as functional ingredients. Int. J. Home Sci. 2 :90-93.

Shukla, K. and Srivastava, S. (2014). Evaluation of finger millet incorporated noodles for nutritive value and glycemic index. J. Fd. Sci. Tech. 51 :527-34.

Singh, A. and Kochhar, A. (2012). Impact of supplementation of functional beverage on the physical performance of sportswomen. Asian J. Home Sci. 7 :260-63.

Srivastava, K. and Sharma, A.K. (2012). Nutraceutical importance of finger millet (Eleusine coracana) for improved human health. European J. Plant Sci. Biotechnol. $6: 91-95$

Sullivan, (2009). Prevent osteoporosis through your diet. https://www.everydayhealth.com

Swer, T., Devi, K., Hymavathi, T.V. and Babu, J. (2013). Development and evaluation of fruit incorporated pearl millet, bajra (Pennisetum.glaucum) malt drink mix. Trends Biosci. 6 :239-43.

Tripathi, B., Platel, K. and Srinivasan, K. (2012). Double fortification of sorghum (Sorghum bicolorL. Moench) and finger millet (Eleucine coracana L. Gaertn) flours with iron and zinc. J. Cereal Sci. 55 :195-201.

Tripathi, J., Gupta, A., Prasad, R. and Puranik, V. (2014). Enhancing micronutrient content of beverage powder by incorporating malted finger millet. Ind. J. Community Health $26: 339-42$.

Vasanthamani, G. and Anuradha, D. (2011). Impact of pregame sports drink on the performance of athletes. Ind. $J$. Nutr. Dietet. 48 :93-98. 